\title{
Görme Biçimleri ve Video Anlatı
}

\author{
Tarık Aylan*
}

\section{Özet}

Bu metinde, Rene Descartes, Brauch Spinoza ve Gotfried Wilhelm Leibniz'in kavramlaryla erken modern dönemde insanın sahip olduğu bakış kavramı belirginleştirilmeye çalışılmıştır. Bu filozoflardan kısa bir süre sonra bakışın mekanik yönünü ve düşüncenin yasaların formülleştirmeye çalışan düşünürlerin çalışmalarn ifade edilmiştir. Temsili imajdan farklı ve insan gözünden bă̆ımsız olarak teknik imaj üretebilen fotoğraf makinasının icadından sonra insan bakış açısı zenginleşmiş ve yeni görme biçimleri kazanmıştır. Bu çalışmada insanın teknik imaj üreten fotoğraf makinası, sinema ve video gibi aparatları kullanarak daha farklı görüş açılarnna sahip olacă̆ı ve düşünebileceği ifade edilmiştir.

Hareketli görüntüyü kaydedebilen sinema sesin de katılımıyla kendine özgü bir anlatı oluşturabilmiştir. Sinemadan yaklaşık 70 yıl sonra ortaya çıkan ve sinemanın anlatısını da taklit edebilen video aygitı zamanımızda birçok alanda kullanılmakla birlikte kendine özgü bir anlatı oluşturmuştur. Bu çalışmada, videonun sanat ve bilimdeki kullanımlarn ile öznelliğe yakın oluşu tanımlanmış ve görme biçimlerine sağlayabileceği yeniliklerin potansiyeli belirginleştirilmiştir. Teknik imaj üreten video ile görüp, bu aygıtla daha farkh düşünebileceğimiz iddia edilmiştir.

Anahtar Kelimeler: Görme Biçimleri, Video A nlatı, Bakış, V ideo A racılığıyla Görmek, V ideo ve Öznellik, Video veSosyal bilimler

*ORCID: 0000-0002-9839-1729

E-Mail: tarikaylan@gmail.com

DOI: $10.31122 /$ sinefilozofi.674337

Geliş Tarihi - Recieved: 15.01.2020

Kabul Tarihi - Accepted: 04.04.2020 


\title{
The Ways Of Seeing And Video Narrative
}

\author{
Tarkk Aylan*
}

\begin{abstract}
In this text, by using the concepts of Rene Descartes, Brauch Spinoza and Gotfried Wilhelm Leibniz, the concept of human view in the early modern period have been tried to clarify. Shortly after these philosophers, the works of the thinkers who tried to formulate the mechanical aspect of the gaze and the laws of thought were expressed. After the invention of phptograph, which is different from the representative image and can produce technical image independently of the human eye, the human perspective has enriched and gained new forms of vision. In this study, it is stated that people will have different perspectives and think by using apparatus such as camera, cinema and video which produce technical image.

The cinema, which can record the motion picture, was able to create its own narrative with the participation of sound. The video device, which emerged about 70 years after the cinema and can imitate the narrative of the cinema, has been used in many fields of our time, but has created a unique narrative. In this study, the use of video in art and science and its proximity to subjectivity have been defined and the potential of the innovations that it can provide to visual forms has been clarified. It is claimed that we can see with the video that produces technical image and think differently with this device.
\end{abstract}

Key Words: Ways Of Seeing, Video Narration, Gaze, Seeing Through Video, Video and Subjectivity, Video and Social Sciences

*ORCID: 0000-0002-9839-1729

E-Mail: tarikaylan@gmail.com

DOI: $10.31122 /$ sinefilozofi.674337

Received - Geliş Tarihi: 15.01.2020

Accepted - Kabul Tarihi: 04.04.2020 


\section{Giriş}

Bakışın diğer duyulardan farklı olarak sahip olduğu ayrıcalık sayesinde ortaya çıkan ürünler ve düşünceler başlangıçta sadece yazı içerisinde ikame etmiştir. Yazılı ürünler sayesinde yaşama dair anlatılar filozofların eserlerinde kendini göstermişlerdir. Özellikle Rene Descartes, Brauch Spinoza ve Gotfried Wilhelm Leibniz'in felsefeleri erken modern dönemden itibaren insanının üzerinde etkili olmuştur. Bu akılcı filozofların çalışmaları modern anlamda bakışın oluşmasında ve önceki dönemlerden farklı görme biçimlerinin belirginleşmesinde önemlidir. 19. Yüzyıla kadar insanın kendine özgü bakışını ve görüşlerini başkalarına aktarabilmek için yazıdan başka bir seçeneği yokken fotoğraf makinesinin keşfiyle bakış konusunda bambaşka değerler dizgesine bir geçiş yapılır.

Fotoğrafın ortaya çıkış yıllarının Sanayi Devrimi sürecinin yaşandığı yıllara denk gelmiş olması belki rastlantısal olabilir ama fizik ve kimya gibi disiplinlerin gelişmesiyle bilimsel düşüncenin belli bir aşamaya gelmiş olmasının bu aparata olan katkıları da azımsanacak gibi değildir. Fotoğrafın icadından sonra ise görüş konusunda bir paradigma atlayışının yaşandığ1 görülmektedir. Göz, görüş alanındaki biricikliğini yitirirken fotoğraf, gerçekliğin bir çeşit izini sunar ve bunu farklı fotoğrafçıların objektiflerinden yapar. Temsili imajdan farklı olan teknik imajla beraber yavaş yavaş insanın bakışı da mekanikleşmeye başlar. Bu aygıt yeni görme biçimleri oluşmasına olanak sağlamıştır.

İnsanın görme biçimi ve kaçınılmaz olarak görüşüyle ilintili düşünme şekilleri onun yer almış olduğu kültürdeki kitle iletişim araçları ve görsel-işitsel ortamların varlığıyla yakından ilişkilidir. Özellikle 20. yüzyılda ortaya çıkan sinema, televizyon ve video gibi görsel-işitsel ortama sahip modern araçlar kişinin görme ve düşünme biçimlerini önemli oranda değiştirmiştir. Geçtiğimiz yüzyılda sinema, dünyayı kısmen temsil edebilmekle birlikte onun insanın duygularını da etkilediği aşikârdır. Böylece insan teknik imaj üreten aygıtlar aracılığıyla kendi gözünden farklı olan bakış açılarına sahip olmuştur. Bakış ile teknik imaj üreten aygıtlar arasında bir benzerlik vardır. Bu aygıtlar aracılığıyla insan, kendi gözünden farklı olarak başkalarının görmüş olduğu imajları görmenin ötesinde "okumaya" başlamıştır. Teknik imajlar temsili imajlardan farklı olarak okunabilen türden imajlardır. Artık okumak için insanın elinde sadece yazı yoktur. Böylelikle bu aygıtlar sayesinde görme ve düşünme biçimleri de değişmiş olurlar.

1965 yılında bir çeşit televizyon uygulaması olarak ortaya çıkan video aygıtı sinemayla karşılaştırıldığında daha farklı bir görsel-işitsel ortam sunmaktadır. Video, sinema için önemli olan ses ve montaj gibi öğelere ilk andan itibaren sahip olmuştur. Kişisel kullanıma daha yakın olan video zamanla modern toplumların birçok alanında kullanılan bir aparat haline gelir. Videonun görsel-işitsel ortamında sinema da dâhil olmak üzere çoğu imaj türünü bir arada görmek ve duymak mümkündür. Video bu anlamda geniş bir kullanım alanına sahiptir. Örneğin polis kayıtlarında, sosyal medyada, trafikte, şehirlerin kalabalık sokaklarında, dükkânların kayıtlarında, eğitimde, günlük yaşamda ve daha birçok alanda video kullanılmaktadır. Sosyal bilimlerde yapılan çalışmalarda da kullanılan video, sosyal bilimlerin antropoloji ve eğitim gibi disiplinlerine de yeni anlayışlar getirmiştir. Video kamerası sinema 
kamerasına oranla kişisel kullanıma daha açı bir aygıttır. Öyle ki feminist sanatçılar enstalasyonlarında videoyu vücutlarının bir uzantısı gibi kullanmışlardır. Video aynı zamanda insanın kendi vücudunu kendi gözünden farklı olan bir bakışla görebilmeyi mümkün kılar. Kısaca ifade edersek video, feminist sanatçıların ve Jean Luc Godard'ın dediği gibi "görüyorum" demektir.

Videonun sosyal hayattaki kullanımı onun bir düşünme aygıtı olarak varsayılmasına olanak sağlar. Gilles Deleuze'ün tanımladığı üç düşünme tarzı yani felsefe, sanat ve bilim, videonun kullanıldığı alanlar olarak düşünülebilir. Diğer bir ifadeyle video, düşünme tarzları oluşturan disiplinlerde sıklıkla kullanılan bir aygıttır. Bu yüzden de tasarlanacak video anlatılar bu alanlarla yani felsefe, sanat ve bilimle doğrudan ilişkili gözükmektedir. Kısaca ifade edilecek olursa video anlatıların bahsi geçen alanlardaki oluşma olasılığı bu araştırmanın aradığ 1 bir cevaptır.

Video ortamının insan üzerindeki etkisi, görme ve düşünme biçimlerinin oluşmasıyla yakından ilişkilidir. Video anlatısı bize farklı bir ortam sunar ve bu aygıt herhangi bir özne tarafından kolaylıkla kullanilabilir. Belgesel filmlerden ev videolarına, sosyal bilimlerden öznelliğe videonun bu kullanım alanlarında video anlatıların tasarlanması mümkün olabilir. Video anlatıyı belirginleştirmek için ise video ile nasıl gördügümüzü, ayrıca onun sosyal bilimlerle ve öznellikle olan ilişkisinin tanımlanması gerekmektedir. Çünkü bu araştırmanın amacı video anlatıların felsefe, sanat ve bilimde yeni görme biçimleri sunabilme potansiyelinin belirginleştirilmesidir.

\section{Moderniteye Doğru: Bakış}

Descartes, Spinoza ve Leibniz'in felsefi çalışmaları daha önceki çalışmalardan farklı olarak başka türden görme ve düşünme biçimleri oluşmasına yol açmıştır. Özellikle Descartes, Spinoza ve Leibniz'in felsefelerinde görme ve düşünme biçimleriyle ilgili kavramlara ve ifadelere rastlanir.

Martin Jay'e göre görme gücünün yaratıcı çeşitliliği Kartezyen felsefesinin başlangıcını oluşturduğu gibi görüşü merkeze alan modern bir anlayışın (ocularcentrism) da temelini oluşturur. Kartezyen felsefesinin temsilcisi Descartes gözlemlenen dünyayı tekrar oluşturmak için "Camera Obscura"sını ${ }^{1}$ perspektif çizimlerinde kullanan bir ressam gibi çalışmıştır. Dolayısıyla Kartezyen Perspektifçilik modern dönemin baskın görsel rejimine (scopic regime) onu kısa yoldan betimleyerek hizmet etmiş olur (Jay, 1994: 69-70).

Descartes Optik isimli eserinin beşinci söyleminde gözün arka tarafında biçimlendirilen imajdan bahseder. Bu söyleminde Camera Obscura'nın tarifini biraz değiştirerek kullanır. Yeni ölmüş bir insanın gözünü ya da öküz gibi büyük bir hayvanın gözünü Camera Obscura'nın deliğinde mercek olarak kullanılmasını önerir. Bunu yaparken mercek olarak kullanılacak gözün arka tarafında bulunan üç adet zarın gözdeki salgıyı dışarı çıkartmadan alınması gerektiğini belirtir. Böyle bir düzenek hazırlandıktan sonra Camera Obscura'sının beyaz bezi üzerinde dışarıdaki nesneleri doğal bir perspektif içinde temsil eden bir resim elde edileceğini ifade eder (Descartes, 1985: 166).

\footnotetext{
${ }^{1}$ Karanlık ve kapalı bir iç mekâna küçük bir delikten ışık girdiğinde, deliğin karşısında duran duvarda ters bir imge oluşturacağı en azından iki bin yıldan beri bilinmektedir. Oklid, Aristoteles, İbni Heysen, Roger Bacon, Leonardo ve Kepler gibi birbirinden çok uzak düşünürler bu fenomeni kaydetmişler ve bunun insanın görmesiyle koşutluk oluşturup oluşturmadığını sorgulamışlardır (bkz. Crary, 2010: 39-40).
} 
Crary'e göre Descartes'ın tanımını verdiği bu düzenek aracılığıyla göz, yüceltilmiş bir konuma yükselir ve bizleri görebilen Tanrı'nın bakışına benzer bir açı sağlar. Artık göz metafizik bir özellik kazanmıştır. Ayrıca tek gözle görmenin getirmiş olduğu teolojik farklılık aracılığıyla sağlanan kanıtlar, dış dünyadan duyu algısı vasıtasıyla elde edilen ve dolayısıyla şüphe duyulabilecek kanitlardan daha üstün olmuş olur (Crary, 2010: 60-62).

Spinoza'da ise Kartezyen ikicilik (düalizm) ve çoğulculuk ortadan kalkar. Her ne kadar Descartes duyudan bağımsız olarak zihnin beden üzerinde etkide bulunabileceğini kabul etmiş olsa da düalizm konusundaki görüşünü değiştirmemiştir. Spinoza'da ise özne ve nesne arasındaki etkileşim dâhil olmak üzere zihin ve beden tek bir olgusallığın farklı yönleri olarak görülmüştür. Spinoza'ya göre kendiliğinden ve kendisi için var olan yani mutlak tanrısal olan bir töz² vardır ve bu töz, sıfatlar ${ }^{3}$ sonsuzluğuna sahiptir. Bu sıfatlardan ikisi yani düşünce ve uzam insan tarafından bilinebilir. Böylelikle zihin, tözün düşünce sıfatı altındaki geçici nitelikleri yani kiplikleri ve nesneler de aynı tözün uzam sıfatı altındaki değişiklikleri olmuş olur. Bu tanımlamayla Kartezyen düalizm sorunu biter çünkü artık özne-nesne ya da zihin- beden iki ayrı şey değil tek bir tözün benzer özellikler gösteren değişiklikleridir (Copleston, 1997: 19,27).

Spinoza'ya göre karmaşık yapıda imajlar oluşturabilen insanın ruhunda duygulara yol açan şey imajlardır. Ayrıca Spinoza "Sevgi ve Nefret" öğretisini oluşturduktan sonra bu öğretiyi baz alarak diğer duyguları tanımlamış ve bu öğretideki her şeyi imajları koruyabilme yeteneğine bağlamıştır. Böylelikle imajlar bakış açılarına bağımlı olmuş olurlar. Spinoza bize, bir at nalı izi gören köylü ile aynı izi gören askerin düşüncelerinin birbirinden farklı olduğunu söyler. Köylü gördüğü izi ekim ve hasat imajlarıyla karşılaştırırken, asker ise izi savaş arabası, vb. şeylerle özdeşleştirebilir (Baker, 2010: 208-209).

Descartes ve Spinoza'nın felsefeleri modern dönem paradigmasının anlatısal olarak ana eksenini oluşturur. Descartes'in Cogito'su modern insanın öznel bakışıyla yakından ilişkilidir. Descartes'dan itibaren öznel bakış açısından bahsedilebilir. Düşünmek ve bakış açısı arasında bir paralellik vardır. Spinoza'nın duygulanışlar öğretisi ise bugün hala modern insanın günlük hayatta yüzleştiği durumlarda kullanılmaktadır.

2Spinoza (2006) Tanım III'de cevheri (Türkçe'si töz) kendi başına var olan ve kendisi ile tasarlanan, yani kendisini teşkil edecek başka hiçbir fikrin yardımı olmaksızın hakkında fikir edinilen şey olarak tanımlamaktadır (s. 31)

${ }^{3}$ Tanım IV'de ise Spinoza, cevherde, onun özünü meydana getirmek üzere algılanan şeye sıfat ya da yüklem demektedir (attribut kelimesi mantıkta yüklem, metafizikte sıfat olarak karşılanırken Spinoza burada her ikisini birden kastetmektedir). Yine Tanım VI'da Spinoza mutlak olarak sonsuz bir varlığa, yani sonsuz sıfatları olup başsız ve sonsuz (ezeli) özü bu sonsuz sıfatlarında her biriyle ifade edilmiş olan cevhere Tanrı dediğini belirtmektedir (s.32) 
Leibniz'in mikro kozmos ve sonsuzluklar üzerine olan çalışmaları bilimlere bakış açısının önemini hatırlatmıştır. Leibniz'in çalışmaları bakış açıları ve görme biçimleriyle doğrudan ilişkilidir. Metafizik çalışması Monadoloji'de bakış açılarının çokluğu sezilmektedir; şöyle ki aynı şehirde yaşayan insanlar evlerinden çıtıktan sonra şehrin belli sokaklarını, meydanlarını, mekânlarını dolaşırlar ve sonunda yine belli rotaları izleyerek evlerine dönerler böylelikle kendi perspektiflerinden gördükleri bir kenti yaşamış olurlar. Bu örnek üzerinden düşünülürse kentler ve benzer şekilde dünya bir arada mümkün olan perspektifler toplamından oluşmuş olur. Rönesans anlayışından farklı olan bu çoklu perspektif pek tabii ki yeni bir özne anlayışını da ortaya çıartır (Baker, 2011b: 118).

"Perspektivizm önceden tanımlanmış bir özneye bağımlı olma anlamına gelmez: tersine, görüş noktasına ulaşan ya da daha doğrusu görüş noktasında duran şey özne haline gelir... Görüş̧ noktası özneye göre değişmez, en azından ilk olarak değişmez; tersine görüş noktası, olası bir öznenin bir değişmeyi (metamorfoz) ya da bir şey=x'i (anamorfoz) kavramasının koşuludur" (Deleuze, 2006a: 31-32).

Leibniz ve Spinoza'nın felsefelerinde kendilerine özgü olan bir perspektivizm hissedilmektedir ve ayrıca onlar iyi birer görme filozofu olarak da okunabilir. Leibnizci perspektivizm çerçevesinden bakıldığı zaman öznenin bir bakış açısına yerleşmeden önce özne olmadığı, ta ki özneleştiren bir bakış açısına yerleştiği zaman özne olduğu gözükmektedir. Nihayetinde Leibnizci bakış açısı için, içine yerleşecek bir özneden önce gelmektedir denilebilir (Baker, 2011b: 278).

Descartes, Spinoza ve Leibniz gibi akılcı filozofların çalışmalarının yanı sıra 17. yüzyıldan başlayarak günümüze kadar bakışın başat konumda olmasının önemli sebeplerinden bir diğeri de teleskop ve mikroskop gibi aygitların bulunmaları sonucunda değişik bakış şekillerinin ortaya çıkmasıdır.

Optik icatlardan önce sezgilere ve algılara direnen dünyanın içi bu aygıtlardan sonra artık ulaşılabilir olmuştur. Mikroskop aygıtı, biyoloji alanında olduğu gibi, bilimlere nesnel ve metotlu bir araştırma olanağı sunarken felsefe açısından da atomizmi yeniden uyandırmıştır. Bu aygıt aracılığıyla görülen dünyadaki küçük canlıların insan hayatındaki doğum ve hastalık gibi olgulardaki önemi metafizikçilerin gözünden kaçmamıştır. Böylelikle daha önceden yaşamda yakalanamayan yönler insan merkezli tanrı bilimsel sistemle uzlaştırılmaya çalışılmıştır (Baker, 2011b: 227).

\section{Teknik İmajın Ortaya Çıkması}

Fotoğraf makinesinin icadı ilkel topluluklar hariç tüm dünyayı etkilemiş ve bu yeni dönüşümde ortaya çıkan insan tipleri yaşanılan gerçekliğin izlerini bir düzleme aktarabilen fotoğraf makineleri vasıtasıyla zamanın belgelerini ve izlerini oluşturmaya başlamıştır. Böylelikle ilk dagerotiplerden itibaren fotoğraf toplumsal bir konuma yerleşmiş olur.

Bu dönemde oluşan yeni yaşam biçimleri doğal olarak yeni görme biçimlerini de beraberinde getirmiştir. Önceleri temsili imaj aracılığıyla işleyen sanatçının okunabilirliği artık 
insan gözünden bağımsız olarak fotoğraf makinesiyle oluşturulan teknik imajlarda fotoğrafı çeken kişinin görme biçimi haline gelmiştir.

"Tarafsız olduğu sanılan mercek, gerçekliği sayısız değişikliğe uğratma yeteneğine sahiptir; çünkü görüntünün özellikleri, her seferinde, fotoğrafı çeken kişinin görme biçimi ve ortaklarının istekleri tarafından belirlenir" (Freund, 2008: 9).

Fotoğraf aygıtının icadından sonra insan gözü görüş alanındaki tekliğini yitirir. Artık insan gözünden bağımsız bir aparatla görme söz konusu olmuştur. Bu durum görüş alanında yeni bir paradigma oluşturmuş dolayısıyla görme biçimleri ve bakış açıları fotoğraf aygitıyla birlikte değişmiştir.

İlk fotoğrafların oluşturulması insanın çizim yeteneğinden bağımsız bir şekilde 1şık, düzenek ve kimyasal maddeler aracılığıyla gerçekleştirilmiştir. Böylelikle ışıkla yazılan yeni bir imaj ortaya çıkmıştır. Dolayısıyla önceki imaj anlayışlarından bir hayli farklı olarak gerçek görüntünün neredeyse anlık ve tekrardan üretebilen izlerinden bahsedebilir. Artık klasik temsil anlayışla oluşturulmuş imajların dışında olgusal dünya görüntüsünün izi ve Vilem Flusser' in deyişiyle aygıt tarafından üretilen bir "teknik görüntü" nün varlığı söz konusudur.

Fotoğrafın icadından sonra teknolojinin özellikle elektrik ve elektronik alanının da gelişmesiyle birlikte sırasıyla fotoğraf, sinema, televizyon, video ve bilgisayar aracılığıyla oluşturulan görüntülerle günlük hayatta sıklıkla karşılaşılır. Bu yüzden Flusser' in teknik imaj ve temsili imaj arasında yapmış olduğu ayrım farklı bir öneme sahiptir.

Bir aygıt tarafından üretilen görüntüler teknik imajlardır. Gerek tarihsel açıdan gerekse varlık bilimsel yönden teknik imajlar geleneksel görüntülerden - temsili imajlardanfarklıdır (Flusser, 2009: 11).

Fotoğraf makinesi aracılığıyla, sabitlenebilen dış bir gerçekliğin yüzey üzerinde izi oluşturulur. Resim ise fotoğrafın icadıyla kendi temsiline kavuşmuş, benzerliği ya da tasviri gösterme çabası da ortadan kalkmıştır.

“Temsili kompleks"ten kurtulan çă̆daş ressam fotoğrafın veremeyeceği kavramları resmetmeye başlamıştır" (Bazin, 2000: 18).

Fotoğraf makinasının bulunmasıyla insanın görüşü de değişmiştir. Görünen objeler farklı bir anlama gelmeye başlamış ve bu durum resimlere de yansımıştır. Artık resmin anlamı söylediğinde değil, ne olduğundadır (Berger,1999: 18, 21).

Söz konusu imajların okunuşları da farklıdır. Flusser'in belirttiği gibi teknik imajları anlamak onları seyretmek ve ardından okumaktan geçer. Hâlbuki resim, plastik ve grafik sanatlarının temsili imajları seyredilmeye ve görülmeye tahsis edilmiştir (Baker, 2011: 65).

\section{Bakışın Mekanikleşmesi}

Modern dönemde filozoflarla bilim adamlarının çalışmaları ve icat edilen fotoğrafsinematograf aygıtları insanın görme ve düşünme biçimlerini köklü bir şekilde değiştirmiştir. 
Bu dönemde ortaya çıkan pozitivist yaklaşımlar görüş ve düşünceyi neredeyse matematiksel bir formda tanımlar hale gelmiştir.

19. yüzyılda Sir David Brewster, Joseph Plateau ve Gustav Fechner isimli bilim adamları güneşle tuhaf bir görsel ilişki kurmuşlardır: Art-imgelerle alakalı araştırmaları sırasında güneşe doğrudan baktıklarından görüş kabiliyetlerini zedelemişlerdir. Öyle ki Fenakitoskop'un mucidi Plateau görme yetisini bu araştırmalar için tamamen kaybetmiştir. Doğrudan güneşe bakılmak suretiyle yapılan bu çalışmalarda güneşin bedende oluşturduğu akkor halindeki renk çoğaltılmaya çalışılırdı. Bu bilim adamlarının çalışmaları dış dünyadaki nesnelere karşılık gelmeyen ve dışımızdaki nesneleri temsil etmeyen bir görüş şeklinin varlığıyla ilişkiliydi. Başka bir deyişle, görmenin biçimleştirilmesi ve mekanikleştirilmesiyle ilgilenmişlerdir (Crary, 2010: 153-154).

Bahsi geçen bilim adamlarından Fechner, dişsal uyarıları ölçerek duyumu rasyonelleştirmeye çalışmış ve duyumları niceliksel olarak saptamayı başarmıştır. Bunun sonucunda duyum ve uyarıcı arasında işleyen matematiksel bir denkleme ulaşmıştır: $\mathrm{S}=\mathrm{k} \log \mathrm{r}$. "Fechner Yasası" olarak geçen bu formüle göre $\mathrm{S}$ duyum $\mathrm{r}$ ise uyarıcının sembolüdür. Fechner daha önce hiç ölçülememiş bir şeyi niceliksel olarak saptamayı başarmıştır. Ayrıca Fechner deneylerini yaparken cebir ve mantık işlemlerini kullanarak düşüncenin yasalarını da formülleştirmeye çalışmıştır (Crary, 2010: 158-159).

Fechner'in araştırmaları sayesinde duyum ve onun dişsal nedeni arasındaki ilişkinin keyfi olduğu saptanmıştır. Daha doğrusu tahmin edilmekle birlikte duyudaki artışla uyarıdaki artış arasındaki ilişkinin düzgün doğrusal bir orantıya sahip olmadığı bulunmuştur (Crary, 2010: 158).

Fechner'den önce "görme" niteliklerin algılanmasıyla ilişkili bir deneyimken modernizm ve Fechner'le beraber duyusal deneyimin niceliksel farklılıklarıyla ilişkili olarak düşünülmüştür. Algının Fechner yasasında olduğu gibi matematikleştirilmesi duyulardaki niteliğin silinmesine sebep olmuş ve artık görmenin modern tanımı logaritmik bir eğri grafiğinden elde edilir hale gelmiştir (Crary, 2010: 160).

Modern ve birbirinden farklı olan görme rejimleri ise fotoğraf makinesi ve sinema gibi modern aygıtların icadından sonra klasik görme modellerinden farklı olarak ortaya çıkmışlardır. Bu icatları modern toplumda yeni yaşam şekilleri edinmiş insandan soyutlayarak ele almamak gerekir.

Düşünce Deleuze'e göre farklı biçimlere bürünebilir: Örneğin felsefe, bilim ve sanat birbirinden farklı eğilimler ya da güçlerdir. Ne kadar çok düşünme biçimi varsa o kadar da dünya vardır. Gerçekte düşünmenin neler yapacağını tam olarak bilemeyiz ama felsefe, sanat ve bilimi oluşturabilirsek düşüncenin üretken olduğunu söyleyebiliriz. Deleuze'e göre bir bütün olarak düşünme hayat olayıdır ve bu üç düşünme tarzı yani felsefe, sanat ve bilim sürekli oluş sürecindeki hayatın dinamikleridir (Colebrook, 2004: 11-26). 
Filozofların düşünme konusundaki yaklaşımları birbirinden farklı da olsa genel olarak insanın algısı, algıladığı imajlar sonrasında imgeleminde oluşanlar, bildiği kavramlar, fikirleri ve tüm bunlarm birbiriyle ilişkili olduğu bütünlük modern dönemde düşünme eylemi olarak yorumlanir.

\section{Teknik İmajlarla Görmek ve Düşünmek}

Sinematografi ve kinetoskop aygıtlarının icadı insanın dünyaya bakışını değiştirmiştir. İnsan artık gidemediği yerleri veya göremeyeceği şeyleri bu aygıtlar aracılığıyla hareketli olarak tekrar tekrar izleyebilme imkânına sahip olmuştur.

20. yüzyılın başında yeni olan bu görsel-işitsel ortamın yapabileceklerine içinde barındırdığı potansiyelden ötürü oldukça inanılmıştır. Kısa bir süre sonra sesin de katılımıyla artık sinema, dili de içermiş olacaktır. Sinemada dilin olması var olan gücüne güç katacak ve onu oldukça önemli bir kitle iletişim aracı haline getirecektir. 20. yüzyılın ikinci yarısından sonra ise teknolojinin de gelişmesiyle sinematografi ve kinetoskop makineleri görüntü kalitesi yüksek kameralara dönüşmüştür. İnsan gözüyle sinema kamerasının bakışı arasında kurulan paralellik artmış ve izlemeyle ilgili teknolojiler de gelişmiştir.

Sinematograf ve kinetoskoptan sonra dünya, "kaydedilebilir hale" gelmiştir. İnsan görüşü mekânın sınırlılığından kurtulmuş, bu aygıtların ulaşmış olduğu yere kadar gidebilmiştir. Toplum yaşamına hızlı bir şekilde katılan sinematograf aygitı yeni görme biçimleri oluşturmuştur.

Modern döneme ait bir sanat olan sinema 20. yüzyılın başında oluşan görsel ve işitsel ortamı sayesinde düşünme ile imgelem şekillerini değiştirmiş ve görme biçimlerinde çeşitlilik oluşturmuştur. İnsan sinema sayesinde organik gözün sınırları dışındaki dünyayı algılamış ve filmlerde anlatılan düşünme tarzına sahip olmuştur. Sinema kişinin kendi görüşünden başka farklı algıları ve değişik yaşantıları yine insan algısının anlayabileceği bir tarzda gösterebilmektedir.

Spinoza'ya göre düşünmek olarak adlandırılan şey fikirlerin düzeniyle şeylerin düzeninin benzer kılınmasıdır. Başka bir deyişle, Spinoza, felsefesinde beynin işleyiş düzeniyle şeylerin işleyiş düzeninin birbirine uygun hale geldiğini göstermiştir. Deleuze, Spinoza gibi Dziga Vertov'u insan beyninin işleyiş sistemini iyi kavramış biri olarak görmüştür çünkü Vertov filmlerini pratik anlamda kendisinin aralıklar kuramındaki ilke doğrultusunda oluşturmuştur. Beynimizdeki işleyiş kabaca nöronların etkileşimi sonucu birbirleriyle bağlar oluşturan ünitelerin ilişkisi olarak tanımlanabilir. Bu karmaşık bağ1 oluşturan üniteler ise kendilerine göre kümelenmiş imajlar, hafıza, algılar ve fikirler gibi kendilerine özgü topluluklardır. Vertov'un aralıklar kuramında işleyen şey ise imajların kurgulanması değildir imajlar arasındaki bağlantının ve imajlar arası alanın tüm kümesidir. Vertov'un filmleri, özellikle Chelovek s kino-apparatom (Kameralı Adam, Dziga Vertov, 1929) beynin işleyişinin sanki bir imajlar organizasyonu aracılığıyla ekrandaki izdüşümü gibidir. 
Hayatı hareketler ve yavaşlıklarıyla, uzaktan algılamalarla en önemlisi aralıklarla kaydetmiştir (Baker, 2011a: 214-215, 221, 341).

Vertov'un sine-göz kuramı doğrultusunda kamera kendi gerçekliğini yakalar ve bu açıdan bakılırsa kamera öz bilinçlidir. Ayrıca sine-göz anlayışına göre algı maddenin içindedir dolayısıyla Leibniz'in monadolojisinde olduğu gibi herhangi bir kenti oluşturan bina, yol, park gibi mekânların sanki bir bakış açısı varmış gibi hissedilir. Vertov ve Kinoklar sıradan anları yakından kaydedip bunları başka hareketli anlarla montajlamışlardır. Böylelikle ortaya çıkan bütün düşünülmüş olur. Başka bir deyişle, düşüncenin bakış açısı olayların kaydedilmesinde ve montaj sırasında ayıklanıp seçilmesinde bir kişiliğin var olmasıyla ortaya çıar (Frampton, 2013: 85-86).

Sinematografinin gücüne yürekten inanan Sergei Eisenstein'a göre ise seyirci filmin bütünde oluşturduğu temayı algılayabilmek için normal kavrayış şekillerini terk edip bir çeşit kendinden geçme haline ulaşmalıdır. Aslında biz izlemeden öncede bir bütün halde olanfilm zaten düşünüyordur yani bizim düşünebileceğimiz bir formda ya da düşünce durumda izlenmeyi bekliyordur. Film bu kendinden geçmeyi "pathos" ile yani filmin alıp götürme duygusuyla ve yaşattığı coşku hissiyle üretir. Böylece filme angaje olan ya da bağlanan izleyici onun düşünme sürecine de katılmış olur (Frampton, 2013: 98).

Eisenstein Vertov gibi beynin işleyiş tarzını fark etmiştir ve ona göre film diyalektik bir biçimde işleyen topolojik kümeler toplamıdır yani bir düşünceden daha üst bir düşünceye, bir duygudan başka bir duyguya ve en sonunda da tekrar bir düşünceye sıçramak şeklinde tanımlanabilir. Bu durum aynen beyindeki nöronların etkileşimi gibi işlemektedir (Baker, 2011a: 216-217).

Görme biçimlerini belirginleştirmek ve sinema anlatısına yakınlaşmak için Gilles Deleuze'ün felsefe ve sinemayla ilgili görüşlerinden yararlanmak yerinde olacaktır.

Filmler yeni düşünme sistemleri ve hatta yeni episteme içerirler. Dolayısıyla yeni düşünme biçimleri oluşturabilirler. Örneğin Deleuze gibi bir filozof için filmler en az bilim ve felsefe kadar kavram oluşturma imkânı sunarlar ve sadece nesneleri izlenmeleri için sunmazlar, düşünme biçiminden kaynaklanan, sundukları bu nesnelere ilişkin görme biçimleri de oluşturabilirler (Frampton, 2013: 26, 85).

Felsefe kavramlarla düşünür ve düşündürtür, sinema, felsefeden farklı olarak imajlarla düşünür ve düşündürtür: Örneğin Deleuze'ün yazdığı Sinema 1: Hareket-İmaj (1983) ve Sinema 2: Zaman-İmaj (1985) adlı kitaplarda felsefede yer alan kavramlarla ilişkili olabilecek imajlar ortaya çıkartılmaya çalışılmıştır (Deleuze, 2003: 19-20).

Kavramlar icat etmeye çalıştığını söyleyen Deleuze, sinema yapanların kavram yerine hareket-süre blokları oluşturduğunu belirtir yani eğer hareket-süre blokları kullanılarak hikâye anlatılmışsa o zaman sinema yapıldığından bahsedilebilir (Deleuze, 2003, 17-21). 
Deleuze'e göre sinema, düşünme ve imgeleme olanaklarını, şekillerini değiştirmiş ve felsefe onun aracılığıyla hayata açılmıştır çünkü insan, sadece sinema sayesinde gözüyle kısıtlanmadan kendi görüş sınırları dışında kalan bir dünyayı, bir düşünme tarzını edinebilir. Sinema bizlere kendi algımızın dışında, herhangi bir kişide konumlanmamış yaşanmışlıkların, anlatıların, verilerin algıya benzer bir halini sunar. Sinema yeni felsefe olanakları oluşturur zira sinema insandaki oluşumların felsefi yönünü besler (Colebrook, 2004: 45).

Deleuze Beyin Ekrandır (1986) isimli konuşmasında, sinemanın insan davranışlarından ziyade insanın ruhsal yaşamını göstermede sahip olduğu inanılmaz potansiyeli gördüğü an onunla ilgilenmeye başladığını söyler. Ona göre ruhsal yaşam ve bir düşünce sürecinin başlaması arasında yakın bir ilişki söz konusudur. Sinema bu ilişkide sürekli olarak beynin bir topoğrafyasını çıkarır (Deleuze, 1986: 2).

Kameranın kavramlar oluşturmadan kaydedebilmesi, görebilmesi ve algılayabilmesi sinemanın en önemli özelliklerindendir. Zira sinema, kameranın insansı olmayan gözünü kullanarak sekanslar oluşturur, bakış açıları yaratır ve bunu tekil herhangi bir gözlemciden bağımsız olarak yapabilme gücüne sahiptir. Böylece gündelik bakış, kemikleşmiş ve daralmış perspektiflerinden kurtulmuş olur (Colebrook, 2004: 47-49).

Sinemada başlangıçta sanat tartışmalarının asıl konusunu oluşturan kamera, bugün araştıran konumundadır. Kamera insan gözüne bağımlı olmayan farklı algılamaların izlenmesine olanak sağlamıştır. Gerçeklik, organik gözden bağımsız olarak gerçekleşen makine algılarının kurgulanmasıyla farklı bir boyut kazanmıştır. Montaj, gerçekliğin içinde oluşan kurgunun ve kurgu içinde meydana gelen gerçekliğin tekrar sunumudur. Zaman, hareketin tekrar ve tekrar üretiminde, kurgusunda, filmin oluşturulması ve izlenmesinde kısacası bütünü oluşturan her aşamada kendi tümlügüuyle sinemaya katılır. Artık hareket yanılsamasının gerçekliği sorgulanmaz olmuş, onun yerine sinemanın imajlarla düşündürttüğü şeyler ve anlamlar önemsenmeye başlanmıştır.

Sanat, bilim ve felsefe gibi düşünme tarzları Deleuzecü terminolojiyle "oluşa" yani bizlerin oluşmasına yardımcı olan araçlar olarak ifade edilebilir. Modern dönem sanatı olan sinema ise kullandığ çeşitli teknikleriyle bizim farklı düşünmemizi sağlamıştır.

Kadraj, çekim, plan-sekans ve montaj gibi sinematografik teknikler ile beklenmedik ilişkilendirmeler, sinemaya özgü duyulur ve kavranır fikirler oluşturarak sinemada kendisi dışında herhangi başka bir öğeye bağlı olmadan yani sinemaya içkin düşünebilme gücünü meydana getirir. Dolayısıyla sinemada oluşan düşünceler bizlerdeki düşüncelerin yansımaları değil bilakis sinemanın kendi içinde gerçekleşen ve ona özgün olan sinema düşünceleridir (Gönen, 2004: 74).

Sinema, kendi dışındaki söylemlere anlatılarını katarak eklenmekte ya da diğer söylemlerdeki anlatıları kendi söyleminde işleyerek oluşumunu devam ettirmektedir. Lumiere Kardeşler'in ilk gösterisinden bu yana geçen bir asır boyunca sinema kuramları çoğunlukla sanat, gerçeklik, hareket yanılsaması, hareket-zaman, görüş biçimleri, algı gibi 
kavramlar etrafında anlatımını gerçekleştirmiştir. Dijital ve elektronik teknolojinin gelişimini kendi lehine işletebilen sinema, görüş, alg1 ve düşünme biçimlerini de derinden etkilemiş ve yeni düşünme yolları oluşturmuştur.

Bugün kamera karşısında hiç yer almamış aktörler ve mekânların kullanımı söz konusudur. Bilgisayar aracılığıyla gerçekte var olmayan oyuncular, mekânlar ve nesneler canlandırılabilir ya da "blue/green box" ile yapılan çekim bambaşka bir görüntü üzerine bindirilebilir. Sinemanın üretilmesi ve izlenilmesi ise dijital ve elektronik ortamlar ile sosyal medya tarafından üstlenilmiştir. Günümüzde artık efektlerin olmadığı bir film izlemek neredeyse imkânsız hale gelmiş, video ve bilgisayar yaratımlı imajların kullanımı geleneksel anlamdaki sinematografik imajları değiştirmiştir.

\section{Televizüel Bir Aygıt: Video}

Teknolojinin gelişimi sinemanın geleceğini doğrudan etkilemiş ve ayrıca sinemadan farklı olarak başka biçimde teknik imaj üretebilen televizyon, video ve dijital video kamera gibi aygıtların oluşmasına neden olmuştur. Bu durumda kavram karışıklığını gidermek ve sinema anlatısını kullanan ortamları belirtmek uygun olacaktır. Örneğin video (bugün sinema olarak adlandırdığımız anlatılar video kameralarla gerçekleştirilir), sayısal ortam (3d animasyon filmleri, AR, VR ve XR ortamları böyledir) ve yine video ya da pelikül üzerinde sinemanın konvansiyonellerini kullanan sinemadan bahsedebiliriz.

Televizyon estetiği üzerine çalışmış Herbert Zettl'e göre televizyonun özünü oluşturan şey onun canlı yayın akışına sahip olmasıdır. Zettl'e göre mekanik olarak üretilen sinema filmlerindeki her bir kare aslında fotografik olarak kaydedilmiş imaj iken televizyondaki görüntü Bergsoncu anlamda sürekli hareket halinde olan ve hiçbir zaman bütünlüğe erişemeyecek yapıdaki ekranın ışın dalgaları tarafından taranmasından oluşur. Bu bağlamda ontolojik açıdan televizyon ve sinemayı karşılaştıran Zettl televizyon karesinin özellikle canlı yayındayken sürekli varoluş halinde olmasına karşın film karesinin geçmişin somut bir kaydını gerçekleştirdiğini belirtmiştir. Dolayısıyla film biz izlesek de izlemesek de kaderi bağlı bir şekilde farklı bakış açılarını ve düşünme şekillerini oluşturmuştur ama canlı yayındaki televizyon gerçek hayattaki belirsizlikler ve değişkenliklerde hayat bulur (Feuer, 1995: 76, 77).

Televizyonculukta video bir anda devreye girer. Video canlı yayın sırasında ya da normal yayın akışında anında yayından kurtulmak için oluşturulmuş bir televizyon teknolojisidir ya da televizüel ortam aparatıdır. Kameraların bağlandığı video mikser sayesinde diğer kameralarla görüntü sağlanır ya da önceden çekilmiş video görüntüler ekrana iletilir.

Sinema kameralarına hemen rakip olamayan video kameralar, buna rağmen dijitalleşerek günümüzde yüksek kalitede çekim yapabilmeyi ve pelikülü rafa kaldırabilmeyi başarmıştır. Video kamera, sinemanın konvansiyonellerinden farklı olarak istenilen şekilde görüntüyü kaydedebilir ve işleyebilir. Aynı zamanda sinema kamerası gibi de işletilebilir. Bu sayede sadece dijital video kameralarla çekilmiş sinema filmleri oluşturulabilmiştir. Dijital 
sistem analog sistemle karşılaştırıldığında kurgu ve efektlere çok daha büyük kolaylık ve pratiklik getirmiştir: Örneğin dijital el kameranızla (Handy-Cam) -ki o da bir video kameradırkaydettiğiniz görüntüyü kişisel bilgisayarınızda kurgulayabilirsiniz. Artık günümüzde çekilen görüntüler video-kasetlere değil, bilgisayarlar tarafından okunabilen hafıza kartlarına ya da sabit disklere kaydedilmektedir.

Televizyon sinemayı dönüştürmüştür. Özellikle videonun televizyonda kullanılmaya başlamasından sonra video ile televizyon için çekilen sinema filmleri, sinemanın televizyon içerisinde kaybolmasına neden olmuştur. Ancak video bu içe doğru olan kıvrılmayı tersine işletebilecek bir potansiyele de sahiptir. Geçmişte gerçekleştirilen gerilla televizyonculuğu, bağımsız sinema, gerilla filmcilik ve belgeselcilik anlayışında video, gücünü göstermiştir. Bu bağlamda televizyon ile video arasında diyalektik bir ilişki var denilebilir. Zira video ile çekilenler kişisel ya da ev videosu olmadığı sürece televizyonlarda gösterilmek durumundadir.

Sinema aparatının konvansiyonellerinde olmayan birçok yeni özellik televizyon teknolojisinden doğan videoda vardır. Matematiksel bir ifade ile belirtildiğinde günümüzde videonun paradigmasının sinemanınkini kapsadığı söylenebilir. Bu durumu doğrulayabilecek örnek olarak sinema filmlerinin dijital video kameralarla çekilmesi verilebilir. Televizyon teknolojisinden türeyen video geç modern dönemde ortaya çıktıktan sonra sosyal hayatta birçok alanda kullanılmaya başlamıştır.

Video kamera amatör anlatıcıların elinde gerçekliği kaydetmeye başladıktan sonra sinema gerçeklikle olan ilişkisini artık tamamen videoya devretmiştir. 1980'li yıllarda aile, düğün ve sünnet dügünü görüntülerinin, videoya aktarılmış sinema filmlerinin ve yine video için çekilmiş sinema filmlerinin oluşturulduğu dönemler yaşanmıştır. Video, belgesel filmcilik için başlangıçtan itibaren çok önemli bir aygıt olmuştur; ayrıca polisin denetimi sağlamasında, sosyal medyada, otobanlarda, eğitimde ve daha birçok alanda kayıt eden bir aparat olarak da kullanılmaktadır. Bu alanlar video anlatı olarak adlandırılabilir.

Nedir bu alanlar? Birincisi belgesel filmlerden ev videolarına videonun çok geniş bir kullanım alanı vardır. İkincisi video, bilimde ve sosyal bilimlerde aktif bir şekilde kullanılmaktadır ve üçüncüsü video öznellikle çok yakın bir bağlantı içindedir. Dikkat edilirse Deleuze'ün üç düşünme tarzı yani felsefe, sanat ve bilim, tanımlanan bu üç video anlatıyla birebir ilişkilidir. Video sosyal hayatta birçok kullanım alanına sahiptir (video ve felsefe). Video bilimde sıklıkla kullanılan bir yardımcı aparattır (video ve bilim). Video özneye olan yakınlığından dolayı sinema anlatısında, dijital alanlarda, sosyal medyada ve video-art uygulamalarında sanatın ortamını oluşturur veya ona eşlik eder (video ile sanat).

\section{Video Aracılı̆̆ıyla Görmek: Belgesel Filmden Ev Videosuna Video}

Her ne kadar etnografik filmler ve Jean Rouch'un filmleri sinema kameralariyla çekilmiş olsa da video kameralar, sağladığı kolaylıklar ve görüntünün anında tekrar gösterilmesi gibi özellikleriyle hep aranan bir konumda olmuştur. Zaten günümüzde etnografik kökenli belgeseller de dâhil olmak üzere belgesel film çekimlerinde video kameralar kullanılmaktadır. 
Günümüz post-hakikat tartışmaları ekseninde insanın gördüğünü doğru kabul etmesi üzerinden gidilirse görüntü ve gerçeğin aynı olduğu söylenebilir. Bahsi geçen aynılık sadece televizyona özgü değildir. Bütün video uygulamaları için bu iddia geçerlidir. Örneğin Körfez Savaşı'nda Irak'a karşı düzenlenen askeri harekât, görsel ve işitsel teknolojiye sahip olan koalisyon gücünün bulunduğu taraftan, video aracılığıyla canlı olarak izlenmişti. Bu gerçekliği videodan ayırmak imkânsızdır.

Günümüz video-oyunlarında, etkileşimli ortamda ya da sanal dünyada kullanıcıların kendilerini bambaşka bir ortamda hissetmeleri ve siber alanın içine gömülmeleri üç boyutlu ya da holografik olan video görüntülerle mümkün olmaktadır. Birçok distopik filmde bu anlamda sanal seks ana tema olarak işlenmiş olmakla birlikte bu filmlerde sanal olan seks, gerçeğine göre daha güvenli ve tatmin edici olarak vurgulanır. Psikanaliz ise bakıştan alınan bu zevk mevzusunu görsellik bağlamında sıklıkla kendisine konu etmiştir.

Video-sanatın dışında video görüntüsü hep gerçekliğin kaydını oluşturur. Spor müsabakalarında, örneğin tenis maçlarında sayı olup olmadığına karar vermek için, bazen video görüntüsüne başvurulur. Videonun gerçeklikle olan bu ilişkisi sayesinde ünlülerin ve politikacıların gerçek olan görüntülerinin tabii ki bazen de manipüle edilmiş haldeki gerçekliklerinin ifşa edilmesi söz konusudur.

Bugün görsel-işitsel teknoloji ve video bir gözetim aygıtı olarak da kullanılmaktadır. Liberal Batı demokrasileri de dâhil olmak üzere birçok devlette elektronik bilgi toplama görsel rejime (scopic regime) resmi olmasa bile fiili olarak hizm et etmektedir. Örneğin Amerika'da Mccarthy ve Watergate ile sonuçlanan Vietnam dönemi gibi en azından iki tane kara film paranoyası zamanı yaşanmıştır. Bu paranoyada ne kadar çok şey bilinirse bilinsin görülecek ve işitilecek daha birçok şeyin var olabileceği duygusu kolayca atlatılamaz. Zira medya patronları, politikacılar ve çeşitli cemaatler görsel rejimi kendi lehine kullanırlar ve birbirlerini çoğu durumda yandaş olarak seçerler. Amerika'da yaşanan bu iki dönemin gözetimleri de bu şekilde taraflı ve eksik olarak açığa çıkmıştır. Dolayısıyla insanlar belki de ilk defa hala bilemedikleri şeyler olduğunu sezinlemeye başlamışlardır (Orr, 1997: 109).

Günümüzde internete bağlanıp televizyon izleyebileceğimiz, üç boyutlu ve $4 \mathrm{~K}$ çözünürlügüündeki videoları da görebileceğimiz akıllı televizyonlar piyasalarda satılmaktadır. Video, televizyon ortamında izlenebildiği için televizyon teknolojisiyle birlikte gelişen bir yapıya sahiptir. Teknolojik olarak ve algısal alışkanlıklarımızdan ötürü televizyon ile video görüntüsünü bir sinema filminin sahip olamayacağı kadar canlı ve gerçek görmeye meyilliyizdir. Filmlerin sinematografik yapısı da video ve televizyonun daha gerçekçi algılanmasına katkı sağlar. Ayrıca olaylar televizyon yayınına anında aktarılabildiği için televizyon ve video bizlere sinema filminden daha gerçekçi görünürler (Feuer, 1995: 77). 
Yayın endüstrisinde ortaya çıkan görsel ve işitsel bu teknolojinin yayıncılık dışı kullanıcılara sunulması videonun birçok alanda kullanılmasına olanak sağlamıştır. En önemlisi de videonun sosyal hayatımızın içine hızlı bir giriş yapmış olmasıdır: Örneğin bugün her cep telefonunda ve bilgisayarda illaki bir video kamera bulunmaktadır. Böylelikle her an sosyal medyada görüntülü iletişime geçilebilmektedir. Ayrıca ev ve iş yerlerinde güvenliği sağlamak amaçlı ya da şehirlerde çeşitli mekânların izlenmesinde de yine video kameralar kullanılır. Sözü edilenler dışında bir de iletişim maksatlı gerçekleştirilen video konferanslar, tatil videoları, evlilik videoları ve günlük yaşamda her an her şekilde kullanılan video türleri de söz konusudur.

Videonun geniş kullanım alanı içinde belirginleşen bir yönü de ev videosudur. Ev videosunda çoğunlukla aile içi görüntülerin kayıtları yer alır ve video her zaman olmasa bile aile içi uzamın hayalî bir sunumunu verir. Ev videosu liberal videonun ve onun teorisinin gayri meşru çocuğu gibi gözükür. Fakat ev videosunun bu kurallara aykırı statüsü popüler kültürün önemli bir bileşeni olarak videonun etkin gücünü ortaya çıkarmaya yarar. Genellikle medya ve entelektüeller tarafından değerli bulunmayan ev videoları bazen ciddi ve sistematik analizlerin yapılmasına da esin kaynağı olabilirler (Moran, 2002: XIV).

Rodney King'in görüntülerinin yer aldığı ev videosu bütün zamanların en ünlü ev videosudur. Bir kış gecesi musluk şirketi müdürü George Holliday yeni satın almış olduğu video kamerasıyla, Los Angeles polisleri tarafından eski hükümlü siyahi Rodney King'in ciddi bir şekilde dövülüşünü apartmanındaki balkonundan kaydeder. Ertesi sabah Holliday Los Angeles televizyon istasyonu KTLA'yı arar ve çekmiş olduğu videoyu 500 dolara satar. Holliday kaydetmiş olduğu görüntülerin birileri tarafından bilinmesini istemiş ve bunun için de en iyi yolun televizyon olduğunu görmüştür. Holliday'in çekmiş olduğu görüntüler her ne kadar bulanık, sallantılı ve düşük 1şıktan ötürü çoğunlukla renksiz olarak görülse de olan biten için çürütülemez görsel bir kayıt oluşturmuştur. Pop sanatçısı Andy Warhol'un da söylediği gibi bu görüntüde çekilen ve çeken kişiler olarak King ve Holliday meşhur olmuşlardır. 1991 yılında gerçekleşen söz konusu olayın yaklaşık bir yıl sonrasında mahkemelik olan Los Angeles polis teşkilatı polisleri bütün Anglo kökenli jüri tarafından suçsuz bulunurlar. Bu süpriz karar Amerika'nın kanlı ve masraflı bir dönem yaşamasına sebep olmuştur. Bu kararın ardından çıkan sivil ayaklanma sonucunda 50 kişi hayatını kaybetmiş, 2300 kişi sakatlanmış, yüzlerce kişi tutuklanmış ve 1 milyon dolarlık maddi hasar meydana gelmiştir. Birçok insan Amerika' da çıkan bu ırkçılık nedenli ayaklanmanın sebebi olarak Holliday'in çekmiş olduğu videoyu görmüştür (Lester, 2000: 269-271).

Ayaklanmalar sırasında olan olaylar yüzünden Holliday'e suçlamalarda bulunulmuştur. Başlangıçta Holliday ölen insanlar için kendisini suçlamışsa da sonraları sadece video görüntüsünü kaydeden kişi olduğunu belirtmiştir. Holliday büyük televizyon kanallarından ve KTLA'den kendisinin izni olmadan videoyu yayınladıkları için 100 milyon dolar talep etmiştir. Amerikan bölge hâkimi anayasa değişikliği özgürlüğü ve çekilen videonun içeriğinin sosyal önemi nedeniyle Holliday'in açtığı davayı reddetmiştir. Hâkim 
şöyle bir ifadede bulunmuştur: "Hiçbir kelime hareketli bir görüntüye bakarak oluşan kamu sezgisinin yerine geçemez". Bu kararıyla hâkim videonun Amerikan kamuoyu oluşumundaki başat konumunu da belirginleştirmiş olur. Yine de Holliday video-kasetten dolayı 150 bin dolar para alır. Ayrıca yönetmen Spike Lee Malcolm X (Malcolm X, Spike Lee, 1992) isimli filminin açılış sekansında Holliday'in çekmiş olduğu videoyu kullanır ve ona bunun için 50 bin ile 100 bin dolar arasında bir ödeme yapar (Lester, 2000: 272).

Videonun şahitliği Rodney King hadisesine benzer birçok durumda kullanılmıştır. Arap Baharı, Suriye iç savaşı, Gezi Parkı olayları ve İsrail-Filistin savaşı örnek olarak verilebilir. Bütün bu olaylarda görsel rejime (scopic regime) sahip olarak onu işletebilen güce karşı telefonuyla ya da video kamerasıyla olan biteni belgelemek isteyen kişiler canları pahasına video görüntüleri elde etmişlerdir.

Bilim, gelişmiş video kameralar aracılığıyla okyanusların dibini, Mars gezegeninin yüzeyini ve hatta yeni doğacak bir bebeğin doğum evrelerini belgeler hale gelmiştir. İnternet uygulamalarının giyilebilir teknolojilere uygulanması sonucu video, Google gözlügüun kenarında bir web kamera olarak yer almıştır ve bilim-kurgu filmlerinde anlatılanların bir kısmı şimdiden gerçekleşmiştir. Video kamera artık beyne gönderilen elektrik sinyallerinin dönüştürülmesinde görmeyenlerin gözünü oluşturmaya başlamıştır.

Videonun halka satışa sunulmasından sonra sanatçılar tarafından kullanılması ise "video sanatı" (video art) ortaya çıkartmıştır. Koreli sanatçı Nam Jun Paik ilk portapak kayıt ünitesi ile video sanatında çeşitli ürünler oluşturmuştur. Paik, televizyon ekranındaki anlaşılabilir olan görüntüyü bozmuş ve bunu video ile kaydetmiştir. Televizyon yüzeyine bir mıknatıs tutmuş ve çizgi roman görüntülerinin bozulmuş haline benzeyen sürrealist görüntüler elde etmiştir. Bu görüntülerin en sonunda ise Richard Nixon ya da Marshall McLuhan'ın bozulmuş yüz görüntüsüne benzer bir imaj üzerinde adalet işareti belirmektedir. Video art öncüsü olan Paik'in buna benzer birçok çalışması vardır (Ross, 1995: 91).

Video art sadece video ile yaplabilen bir sanat iken video, sinema, müzik ve enstalasyon gibi diğer sanatlarla birlikte de kullanılmıştır. Kısa film ve düşük bütçeli filmlerde sinema kamerası yerine video kameralar da kullanılır. Günümüzde kullanılan dijital video kameralar sinema kameralarının vermiş olduğu görüntünün benzerini oluşturmaya yönelik üretilmektedir. Dolayısıyla sinema endüstrisi mekanik-elektronik sinema kameraları yerine dijital video kameraları kullanmaya başlamıştır. Böylelikle elde edilen dijital imaj çok daha kolay işlenebilmektedir. Ayrıca video, görüntünün kaydedilmesinde ve izlenmesinde sinemada olmayan bir kullanım kolaylığına sahiptir.

Görüntüde yer alan simgesel kullanımın baştan çıkarıcılığı video sanatına içsel olduğu söylenebilir. Elektronik video görüntüsünün yapısı doğal olarak maddenin kendisini değil ama ekran üzerindeki hallerine olan hayranlığı da arttırmıştır. Sinema sanatına yönelik ilginin de farklı bir yönden kaynağı olan maddenin bir çeşit enerji oluşu ve elektriğin kullanımı videoya duyulan hayranlığın sebeplerinden biridir (Ranciere, 2008: 69). 
Müzik endüstrisinde klipler video kameralarla çekilmekte ve bu kliplerin gösterildiği ortam yine televizyon olmaktadır. Enstalasyon sanatında ise video ve televizyonun ya da ikisinin birden insanla kurmuş olduğu etkileşim önemsenerek mekânda yerleştirilmeleri söz konusu olmaktadır.

Antik Yunan'da yaşama ilişkin kayıtlar, alıntılar, önemli sayılabilecek olaylar ve fikir yürütmelerin "hupomnemata" sayesinde kaydı oluşturulmuştur. Postmodern olarak görülen zamanımızda ise video ile hupomnematada yapıldığı gibi günlük kayıtlar tutulabilmektedir. $\mathrm{Bu}$, aynı zamanda videonun hatıra amaçlı kullanım özelliğini gösterir. Sosyal medyada güzel görülen, paylaşılmak istenen ya da psikanalizin konu olarak ele alabileceği öznelliğin farklı durumları kullanıcılar tarafından paylaşılmaktadır. Kimi zaman sanal aşklar bile video görüntüsü üzerinden oluşmaktadır.

Videonun teknik imajı elektronik bir şekilde üretilir. Bilgisayar aracılığıyla oluşturulan imajlar teknik imaj kategorisine girse de video imajdan tamamen farklıdır ancak birlikte de sıklıkla kullanılırlar. Video imajlar bilgisayarlar aracılığıyla çok kolay bir şekilde işlem görmektedir.

Video her türlü mekânda kaydedebildiği için her türden imajı toplayabilen nitelikte bir aparattır. İlk olarak kamerayı kullanan ve imajı kaydeden kişiyi kaydettikleriyle ya da yakaladıklarıyla değiştirir sonra seyredenler bu değişimden etkilenir ve dolayısıyla en sonunda da bakış açılarını farklılaştırır. Bu bakış açıları kişiden kişiye değiştiği gibi kişinin kendisinde de bir değişim halindedir. Yakalanan imajlar ise kendine mahsustur yani benzersizdir. Bir görüntüyü iki kere kaydetmek imkânsız olduğu için imajlarla oluşturan film de Leibniz'in monodolojisindeki gibi tek ve biricik olur. Bu yüzden ister video ister sinema filmi olsun aynı filmi çekmek olanaksızdır (Baker, 2011a: 228).

Bugün düşünme, imajlar, kavramlar, alg1 ve fikirlerin birbiriyle bağlantı olduğu bir bütünlüğün eylemi olarak yorumlanır. Bu bağlamda Baker'in iddialı ifadesinde olduğu gibi "Video bir düşünme makinesi olarak tasarlanabilir mi?" Ya da "Tasarlansa bile pratikte bir bütünlük oluşturan düşünme eylemi nereye kadar bu aparatla birlikte işletilebilir?" Video bugün bu sorulardaki eylemleri gerçekleştiremiyor olabilir ama temelde önemli olan şey onun birçok disiplin için sahip olduğu güçlü potansiyeldir.

\section{Video ve Sosyal Bilimler}

Sinema anlatısının oluşturulması ve çözümlenmesi aşamalarında sosyal bilimlerden sıklıkla yararlanılmıştır. Bu ilişkinin tam tersi yani sosyal bilimlerin sinemadan yararlanması da söz konusu olmuştur. Bugün sosyal bilimler, kullanım kolaylığı ve diğer araştırmalara getirmiş olduğu birçok avantajından dolayı sinema yerine videodan da yararlanmaya başlamıştır.

Sinema özünde montajlanmış belgelerden oluşarak geçtiğimiz yüzyılı tümden kaydetmiştir. Her fotoğraf ve pelikül parçası bir çeşit belgedir. Video kamerasıyla 
balkonunuzdan sokakta olan biteni çekerseniz bu bir belge oluşturur. Rodney King olayındaki gibi bir görüntü yakalarsanız hem kanıt hem de video haber olur. Montaj ile bu belgelerin ötesine geçerek bilinmeyen ve görünmeyenleri bir bütün halinde gösterebilme ise belgesel filmi oluşturur. Elbette belgeleri yan yana dizmek ya da arşivlemek değildir belgeselcilik. Onları yeniden kurarak ve yine onlar aracılığıyla onlara bir şeyler söyletmektir (Baker, 2011a: $50,230)$.

Video kameraların antropolojik çalışmalardaki kullanımı yepyeni bir perspektif sağlamıştır. Hantal olan sinema kameraları, var olan kamera hareketlerinin belirli konvansiyonellerini takip etmek zorundadır. Video kameralar ise belgelenen kültürdeki kişilerin ve amatör kullanıcıların çok rahatlıkla kullanabilecekleri bir arayüze sahiptir. Dolayısıyla video kameranın bu yeni yaklaşımları, arkasında ve önünde araştırma yapan kişileri içine rahatlıkla dalınabilecek görsel bir dünya ile sözel olmayan uygulamalara doğru yöneltir. Video kameranın sesi de eş zamanlı olarak kaydediyor oluşu sosyal araştırmalar için bulunmaz fırsatlar sunmaktadır. Yapılan röportajlar, video-teyp kayıtlar, kültür mirasını korumak için yapılan sözlü tarih uygulamaları ve sesin kaydedilmesi ile videonun belge niteliği artmaktadır.

Belgesel film ile etnografik film arasında ayrım yapmak bugün mümkün olsa da başlangıç için böyle bir ayrımda bulunmak pek de doğru olmayacaktır. Dziga Vertov ve Robert Flaherty gibi ilk belgesel filmleri çekenler genellikle antropolog olmayan kişilerdir ve bugün belgesel filmde sinematografik bir görüntü estetiği istenmediği sürece, kaldı ki o da günümüz video kameralarıyla mümkündür, belgesel filmlerin hepsi video ile çekilir.

Daha önce insanlığın karşılaşmadığı bir tarzda arşiv oluşturma anlayışı film ve videonun sadece bir kitle iletişim aracı olarak kullanılmamasıyla, başka bir deyişle bu aygitların belgelendirme niteliğiyle belirgin hale gelir. Zira film daha önce kaydedilemeyen eylemlerin kaydedilip saklanmasını sağlar. (Winston, 1995: 65-66).

Video, belgesel filmciliğe yepyeni fırsatlar sunmuştur. Videonun kullanım özgünlüğü belgesel yapım şeklini bile değiştirmiştir. Örneğin Inga Burrows, Manchester'daki bir sanat galerisinde gerçekleştirmiş olduğu video enstalasyonu ile bir belgesel film çekmiştir. Bu çalışmasında Burrows, dinsel törenlerin şehirde yaşayan topluluklar için önemini araştırmıştır. Burrows, ilkokul, doğum öncesi kliniği ve huzurevi sakinlerini sanat galerisinde belirlenen yere videolar yerleştirerek kaydetmiştir (Grimshaw and Ravetz, 2005: 90).

Video kameraların yaygınlaşmasından önce Amerika ve Kanada yerlilerine sinema kameralarının nasıl kullanıldığı öğretilmiş böylelikle onların bakış açılarıyla çekilmiş görüntüler elde edilmeye çalışılmıştır. Avrupa' da da farklı kültürlerin içinde değişik meslek grubundan insanlara aynı amaçla benzer bir eğitim veren projeler gerçekleştirilmiştir. Örneğin güneybatı Amerika' da yaşayan Navojo yerlileriyle buna benzer bir çalışma yapılmıştır (Worth and Adair, 1975: 3-7). Söz konusu duruma Berberi kültürü hakkında yapılan ve günümüze 
daha yakın bir etnografik çalışma örnek olarak gösterilebilir. Bu çalışmada beklenildiği gibi sinema ekipmanı yerine video kameralar kullanılmıştır (Goodman, 2005).

Günümüzde video kameralardan faydalanılan bir başka alan ise eğitim alanıdır. Görsel- işitsel ortam sayesinde eğitim kalitesi arttırılmış ve bu da video kameralar aracılığılla gerçekleştirilmiştir. Örneğin etkileşimli eğitim programlarında ya da uzaktan eğitim veren online programlarında video kameralardan yararlanılmaktadır.

Video ortamının sağladığı bilgilendirme düzeyi de çok etkili olmuştur. Misal göstermek gerekirse yapılan bir pilot çalışmada, sosyoloji okuyan lisans öğrencilerine video ile sosyal teorileri öğretme stratejileri geliştirilmeye çalışılmıştır. Bunun için çeşitli teorik temalar içeren filmler video aracılığıyla öğrencilere izletilmiştir (Fails, 1988: 256).

Video, belgeselci bir kitle iletişim aracı olarak kullanıldığı gibi ayrıca toplumsal ve tarihsel bir belge olarak da hizmet sunmaktadır. İçeriğinden ayrı olarak anlaşılmanın ve rahatsız edici bir aygıt olarak algılanmanın riskini göze alan video, teknikleriyle birlikte belgesel gerçekliğinin içinde yer almaktadır. Yoksulluk üzerine çekilen bir belgeselde sinematografik ya da renkli imajlar seyircide acıma, üzüntü verme veya itici duygular uyandırabilir (Turim, 1995: 106).

Dijital videonun sosyal bilimciler tarafından kullanılması araştırmalar ve sunumlar için yeni olasılıklar sunar. Dijital teknolojinin getirdiği yeniliklerden bir tanesi de her tekrar üretimde orijinal kalitede ürünlerin elde edilebiliyor olmasıdır. Video kamera ile kaydedilen imajları ve sesleri sosyal bilimciler kişisel bilgisayarlarında depolayıp montajlayabilirler ve nihai çıktıyı yine kişisel bilgisayarlarından istedikleri yerde ve zamanda gösterebilir ya da kullanabilirler (Sooryamoorthy, 2007: 555).

Sosyal bilimlerde videonun bu kullanımı birçok araştırmaya yepyeni anlayışlar getirmiştir. Yaklaşık yirmi otuz yıldır sosyolojide gerçekleştirilen deneye dayalı araştırmalar çoğunlukla karşılıklı etkileşim sırasında gerçekleşen konuşmalar üzerine yapılmaktadır. Etnometodoloji ve konuşma çözümlemesi analizleri konuşmanın, dilin kullanımının ve insanların sosyal eylemler ile aktivitelerini gerçekleştirme yollarının anlaşılmasında büyük katkıları olan alanlar olmuştur. Ucuz ve güvenilir video ekipmanın uygunluğu -ki video aynı zamanda farklı metodolojik kaynakların doğumuna da vesile olur -sosyal etkileşimin doğal analizine öncülük yapar. Dolayısıyla video kayıt sayesinde konuşmalar, beden hareketleri ve görsel-işitsel diğer kaynaklar kusursuz bir şekilde el altında hazır olurlar (Heath, 2004: 266).

Video kameralar sadece sosyal bir olguyu kaydetmekle kalmaz ayrıca sosyoloji için yeni veriler üretir ve sağlarlar. Bu verilerin analizi için bilimsel bir tavırla farklı metotlar oluşturulmuş ve oluşturulmaktadır. Örneğin Thomas Luckmann video etkileşim çözümlemesi için dizisel bir analiz önerir, Lorenza Mondada video uygulamaları için 
prakseolojik ${ }^{4}$ bir yaklaşımı benimsemiştir. Ona göre video datanın sadece nasıl analiz edilmesi gerektiği değil aynı zamanda nasıl çekildiği de önemlidir. Jürgen Rabb ve Dirk Tanzler video hermeneutik olarak adlandırdıkları yaklaşımı önerirler. Onlara göre ise her bir video karesinin anlamı farklı okumalarla en sonunda objektif bir anlama ulaşabilir (Knoblauch, Schnettler, Raab, Soeffner, 2006: 9,19-20).

Sosyal bilimler hala metinsel bir uzama dayansa da bu bilime görsel-işitsel ortamin kattığ1 bilgi azımsanacak gibi değildir. Video sosyal bilimlerin çeşitli disiplinlerine yeni anlayışlar getirmekle beraber bundan sonra da bu tutumunu sürdürecektir. Esasen bugün video aracılığıyla yapılan belgesel filmler video ve sosyal bilimler arasındaki ilişkinin etkili örneklem uzayını oluşturmuş durumdadır.

\section{Video ve Öznellik}

Video performansı ve sanatında isteyerek bozulmuş ve bu yüzden de zor anlaşılır imajlarla sıklıkla karşılaşılır. Dolayısıyla video izleyicisi de video imajları kişisel bakış açısıyla görecektir. Bu yüzden video imaj hem oluşturma hem de izleme aşamasında öznellikle yakından ilişkilidir. Video aparatı aracılığıyla öznellik birçok yönden kaydedilebilir. Başka bir deyişle, kişisel bakış kayıt altına alınabilir. Sözü edilen kişisel bakış bugüne kadar birçok video performans ve sanatta kaydedilmiş ve gösterilmeye çalışılmıştır.

Videoda eş zamanlı kayıtla oluşmuş görüntünün anında monitörden yansıtılması ve insan vücudunun ana malzeme gibi kullanılması video sanatının kısa bir sürede ortaya çıkmasına sebep olmuştur. Diğer görsel sanatlarda olmayan özellikler yani anında kaydedip yayınlama özelliği videoyu özellikle öznel kullanımlar için önemli bir konuma taşır. Monitörden yansıyan görüntü, aynanın dolaysızlığı olmadan gerçek görüntüyle eş zamanlı yansiyan bir görüntüdür (Krauss, 1995: 120).

Video, feminizmin ilerlemesinde de etkin bir rol üstlenmiştir. 1960'l1 y1llarda gelişen politik hareketlerle birlikte feminist oluşumlar görülmüş ve kadınlar bu dönemde konuşmak, görselleşmek ve görünür olmak için sabırsızlanmışlardır. Kadınların çelişen doğaları ve dinleyici-izleyici kitlesine mesajı hemen iletme konusundaki kabiliyetleri, onların video ve onunla oluşturulan performansın çekimine kapılmalarına sebep olmuş ve videoyu kullanarak neredeyse anında feminizm öğretilerini iletmeye başlamışlardır. Böyle bir bilinçlenme pratiğinin ardından video ve imajının mübadele özelliğini kullanarak birbirleriyle iletişime geçmişlerdir. Video kameranın tek bir konvansiyoneli vardır o da onun herhangi bir geleneğe sahip olmayışıdır. Kadınlar 60'ların sonunda sokağa inen videonun bu niteliğini kendi lehlerine çok iyi kullanmışlardır. Video ile kadın öznelliğinin yeni bir sınıflandırması gelişmiş ve kadına ait bir video dili oluşmuştur. Video ile geçen yüzyıllarda yapılmış ataerkil

4 Prakseoloji terimi genel anlamda insan tarafından gerçekleştirilen eylemlerin analizini ifade eder. Daha ayrıntılı bilgi için bkz. Yavuz, Ahmet 'Problem çözümlerine prakseolojik yaklaşım' http://dokuman.tsadergisi.org/dergiler_pdf/2009/2009-Agustos/6.pdf 
yaklaşımların yükünden kurtulma heyecanını yaşayan kadın video sanatçılar, kadınlığın keşfi için nispeten bakir bir alan sunan videoyu önermişlerdir (Elwes, 2005: 41).

Ulrike Rosenbach, Rabecca Horn, Friederike Pezold ve Marina Abramoviç gibi feminist performans sanatçları için ise video "görüyorum" demektir. Bu aparat sayesinde kadın kendi vücudunu kişisel bir bakışla görebilir. Kamerayı vücudunda gezdirip cinsel organının güzelliğini veya çirkinliğini görsel olarak da hissedebilir. Video kamerası sokakta onun gözü kulağı olabilir. Diğer insanların ona nasıl baktığını kamera ile görebilir. (Baker, 2011a: 20).

Kişisel bir araç olarak kullanılan video yani kişiye ait özel görüntüleri saklayabilen videonun biçimlenmesinde video sanat ve enstalasyonla uğraşan feminist öncülerin rolü büyük olmuştur. Videonun öznellik kanadının özünü bu feminist kadınların çalışmaları oluşturmuştur diyebiliriz. Kadın artık kameranın arkasında duran erkek teknisyenler tarafından resmedilmesinin dışında başka bir biçimde görmektedir ve görmek istemektedir. Video ile kaydettiği imajını kendisi nasıl istiyorsa öyle de gösterebilmektedir. Böylelikle televizyon ve sinema dünyasının gösterdiği kadın imajından farklı bir kadın resmi belirmiş olur (Baker, 2011a: 52).

Kadın kendi isteği ile vücudunu videoyla etkileşime sokmuştur. Kadın video ile ekranlarda görsel olarak kurulmuş olan kadının biçimini değiştirebilir. Marksist terminoloji ile ifade edilirse; kadının görsel olarak kurulmuş metalaşmasının zinciri kadınlar tarafından kırabilir. John Berger'in Görme Biçimleri isimli kitabında belirttiği gibi bugün “Kadın kendini bir nesneye-özellikle görsel bir nesneye- seyirlik bir şeye dönüştürmüş̧" ${ }^{5}$ olabilir ama buna video sayesinde bir fark katmıştır. Kadın artık kendini başka bir erkeğin gözünden veya kendi içindeki gözlemci erkek gözünden görmek zorunda değildir. Videoyu vücudunun bir eklentisi olarak kullanabileceği gibi kendi vücuduyla etkileşime sokabilecek bir aparat olarak da kullanabilir ve bütün bunları tek başına yapabilmektedir.

Kişisel belgeleme tarzını "narsist video" olarak da tanımlamak mümkündür. Bu çeşit çalışmalarda video, kendi doğal özelliklerini genişletebilme potansiyelini kullanır. Bazı sanatçılar seyircinin de içinde yer aldığı etkileşimli video ortamının mantıksal sınırlarını genişletmeye çalışmışlardır (Marshall, 1995: 38).

Video sadece kadınlar tarafından değil, aynı zamanda sınıf ayrımına uğradığını düşünen topluluklar, ırk eşitsizliğini belgelemek isteyen kişiler ve eşcinseller için öznel bir şekilde kullanılarak kendilerini rahatça ifade edebilecekleri bir ortam sunmuştur.

\section{Sonuç}

17. yüzyıl akılcı filozofları modern insanın düşünme ve dolayısıyla da görme biçimlerine büyük katkı sağlamışlardır. Descartes'ın felsefesinden bugüne kadar "bakışı merkeze alan" modern bir anlayışa sahip olduğumuz söylenebilir. Spinoza insanın ruhunda duygulara yola açan şeyin imajlar olduğunu günümüzden 350 yıl kadar önce keşfetmiş bir filozoftur.

${ }^{5}$ bkz. Berger, 1999: 47. 
Leibniz'in eserlerinde ise bakış açılarının çokluğu, perspektifler ve mikro düzlemdeki birbirine bağımlı değişkenlerin diferansiyel hesaplamaları gözükmektedir. Bahsi geçen akılcı filozofların çalışmaları ve hemen ardından mikroskop ve teleskobun icat edilmesi önceki dönemlerden farklı görme biçimlerinin oluşmasını sağlamıştır. Ancak yine de bütün bulgular fotoğraf makinesi bulunana kadar bir sonraki kuşağa sadece yazı ile aktarılabilmektedir.

Erken modern dönemde fotoğraf makinesinin icat edilmesi akabinde teknik imajın ortaya çıkması görme ve düşünme biçimlerinde akılcı filozofların yarattığı etkiden farklı bir etki yaratmıştır. Teknik imajlar temsili imajlar gibi sadece görülmeye tahsis edilmiş imajlar değildir, aynı zamanda okunabilirler de.

Modern dönemden az önce ortaya çıkan pozitivist yaklaşımlarda "görüş" ve "düşünce" nin matematiksel olarak tanımlanmaya çalışıldığı görülmektedir. Pozitivist bilim adamları aynen bir makinada olduğu gibi görüş ve düşünmenin biçimleştirilmesi ve mekanikleştirilmesiyle ilgilenmişlerdir. Fechner, duyumu niceliksel olarak saptamış ve "görüş" logaritmik eğri grafiğinden okunur hale gelmiştir. Artık insan gözünü taklit eden makine tasarımlarından değil, makinaları taklit eden görme biçimlerinden bahsedilmektedir.

Teknik imaj üreten sinematografi ve kinetoskop gibi aygitların icadı ile insan kendi gözünden farklı olarak, zihninin dışındaki başka bir ortamda zaman ve hareket kavramlarını seyreder ve "okur" hale gelmiştir. Sinema filmleri sayesinde insan diğer olası dünyaları algılamış ve filmler aracılığıyla anlatılan görme ve düşünme biçimlerinin farkına varmıştır. Yaşama bakış sinema medyası aracılığıyla değişmiş ve yine sinema aracılığıyla yeni ifadeler oluşmuştur.

Deleuze'e göre oluş halindeki hayatın dinamikleri olan felsefe, sanat ve bilim ancak üretken düşünceyle oluşturulabilir. Hareket-süre bloklarından oluşan sinema filmleri felsefe, sanat ve bilimden pay alabilir. Örneğin Chelovek s kino-apparatom (Kamerah Adam, Dziga Vertov, 1929) isimli filminde Vertov sanki insan beyni işleyişine benzer bir şekilde imajların kendisine özgü birlikteliklerini gösterebilmiştir. Sinema filmleri felsefe, sanat ve bilimden pay alabildiği gibi bu argümanın tersi de geçerlidir. Diğer bir ifadeyle sinema filmlerinin görme biçimlerine olan katkısı da yadsınamaz bir gerçektir.

Televizyon için çekilen sinema filmleri, sinemanın televizyon içerisinde kaybolmasına neden olmuştur. Sinema filmlerinin tecimsel oluşu, sinematografinin felsefe, sanat ve bilimden daha çok gişe için oluşturulması ayrıca sinemanın konvansiyonellerinin oluşu onu sınırlandırmıştır. Sinemanın ortamını da taklit edebilen videoda, sinemada olmayan birçok yeni özellik vardır. Başka bir ifade ile videonun paradigmasının sinemanınkini kapsadığ1 söylenebilir. Günümüz sinema filmleri video kameralarla çekilir. Dijital ortamda sinema anlatısı üreten sanal gerçeklik (VR) filmlerinde de video kameralar kullanılır.

Video anlatı olarak üç tane alan tanımlanmıştır. Deleuze'ün üç düşünme tarzı olarak adlandırdığı felsefe, sanat ve bilim, tanımladığımız üç video anlatıyla ilişkili olarak görülmüş̧tür. Örneğin sosyal hayatta kullanılan video uygulamalarıyla felsefeye 
yakınlaşılabilir. Videodan bilim alanında da yararlanılır. Videonun kullanım kolaylığı ve rahat erişilebilirliği onu özneye yakın yapmıştır. Konvansiyonel sinema anlatısında, dijital platformlarda, sosyal medyada ve video-art uygulamalarında video, sanata hep eşlik eder. Video anlatılar bahsi geçen bu alanlarda sanki kendiliğinden oluşma potansiyeline sahiptirler.

$\mathrm{Bu}$ çalışmada erken modern dönem ile post-modernizm arasındaki görme biçimlerinin betimlenmesinin sebebi videonun yeni görme biçimleri oluşturan bir aparat olarak konumunun belirginleştirilmesiydi. Video farklı alanlardaki kullanımından ötürü yeni bir anlatı alanı oluşturmuştur. Bu araştırmada, tanımlanan video anlatıların görme ve düşünme biçimlerine yeni pratiklikler getirdiği görülmüştür. Görsel işitsel imajlar oluşturmasındaki bağımsızlığı ve kolaylığı sebebiyle video insan algı ve fikirlerinin bütünlüğüne doğrudan etkide bulunan bir aparattır. Videoyla oluşturulan görme biçimlerinin devam ediyor olması videonun sinematografiden güçlü olan yönlerinden biridir. Sonuç olarak video anlatıları belirginleştirilerek sanat, bilim ve felsefe düzleminde videonun farklı örüntü yapıları oluşturabileceği düşüncesine ulaşılmıştır. Dolayısıyla video insanın düşünme eylemine etkisi yüksek olan bir makine olarak algılanmalıdır.

\section{Kaynakça}

-Baker, Ulus (2011a). Beyin Ekran. İstanbul: Birikim Yayınları.

-Baker, Ulus (2010). Kanaatlerden İmajlara: Duygular Sosyolojisine Doğru. İstanbul: Birikim Yayınları.

-Baker, Ulus (2011b). Yüzeybilim- Fragmanlar. İstanbul: Birikim Yayınları.

-Bazin, Andre (2000). Sinema Nedir, İstanbul: İzdüşüm Yayınları.

-Berger, John (1999). Görme Biçimleri, İstanbul: Metis Yayınları.

-Crary, Jonathan (2010). Gözlemcinin Teknikleri: On Dokuzuncu Yüzyılda Görme ve Modernite, İstanbul: Metis Yayınları.

-Colebrook, Claire (2004). Gilles Deleuze. Ankara: Kitle Yayıncılık.

-Copleston, Frederick (1997). Descartes, İstanbul: İdea Yayınevi.

-Deleuze, Gilles (1986). Gilles Deleuze'le Konuşma. Beyin Ekrandır: Sinema' da Felsefe Üstüne, Nisan Kitap 07 - Sinema Özel Sayı.

-Deleuze, Gilles (2003). İki Konferans, İstanbul: Norgunk Yayınc1lık.

-Deleuze, Gilles (2006a). Kıvrım - Leibniz ve Barok, Ankara: Bağlam Yayıncılık.

-Descartes, Rene (1985). The Philosophical Writings of Descartes, Cambridge: Cambridge University Press,

-Descartes, Rene (1996). Söylem - Kurallar - Meditasyonlar, İstanbul: İdea Yayınevi. 
Antropoloji,

-Doğan, Hülya (2013). Antropolojinin Görseli Yeniden ve Yeniden Keşfi: Görsel

İletişim Kuram ve Araştırma Dergisi, Gazi Üniversitesi- İletişim Fakültesi - Süreli Elektronik Dergi

-Elwes, Catherine (2005). Video art: A Guided Tour, London: I.B. Tauris.

-Fails, V. Elanor (1988). Teaching Sociological Theory Through Video: The Development of an Experimental Strategy, 28.07.2014 tarihinde http://www.jstor.org sitesi: /stable/1317527? origin=JSTOR-pdf adresinden alındı.

-Feuer, Jane (1983). Canlı Yayın Kavramı: İdeoloji Olarak Ontoloji, Levend Kılıç içinde, Video Sanatı (s. 76-77), İstanbul, Hil Yayın.

-Flusser, Vilem (2009). Bir Fotoğraf Felsefesine Doğru, İstanbul: Hayalbaz Kitap.

-Frampton, Daniel (2013). Filmozofi, İstanbul: Metis.

-Freund, Gisele (2008). Fotoğraf ve Toplum, İstanbul: Sel Yayıncılık.

-Goodman, Jane E. (2005). Berber Culture on the World Stage: From Village to Video, USA: Indiana University Press.

-Gönen, Metin (2004). Paradoksal Sanat Sinema, İstanbul: Es Yayınları. Intelect.

-Grimshaw, A. \& Ravetz, A. (Ed.). (2005). Visualizing Antropology, USA: New Media

-Heath, Christian (2004). Qualitative Research, London: Sage Publications.

-Jay, Martin (1994). Downcast Eye, London: University California Press.

-Knoblauch, H., Schnettler, B., Raab, J. \& Soeffner, H. G. (2006). Video Analysis Methodolgy and Methods, Peter Lang, Frankfurt am Main.

-Krauss, Rosalind (1986). Video: Narsizm Estetiği. Levend Kılıç içinde, Video Sanatı (s. 120), İstanbul, Hil Yayın.

-Kovacs, Andras Balint (2010). Modernizmi Seyretmek, Ankara: DeKi.

-Lester, Paul Martin (2000). Visual Communication, USA:Wadsworth.

-Marshall, Stuart (1979). Video: Teknoloji ve Uygulama, Levend Kılıç içinde, Video Sanatı (s.34), İstanbul, Hil Yayın.

-Moran, M. James (2002). There Is No Place Like Home Video, USA: University of Minesota Press.

-Orr, John (1997). Sinema ve Modernlik, Ankara: Ark Yayınevi.

-Ranciere, Jacques (2008). Görüntülerin Yazgısı, İstanbul: Versus Kitap.

-Ross, David (1986). Gerçeklik ya da Sonuçlar: Amerikan Televizyonu ve Video 
Sanatı. Levend Kılıç içinde, Video Sanatı (s.90-91), İstanbul, Hil Yayın.

-Spinoza, Benedictus Baruch (2006). Etika, Ankara: Dost Kitabevi Yayınları,

Sooryamoorthy, Radhamany (2007). Making Research Film in Sociology, 03.07.2014 tarihinde http:/ / iss.sagepub.com/ sitesi adresinden alındı.

-Turim, Maureen (1983). Video Sanatı: Bir Gelecek Kuramı. Levend Kılıç içinde, Video Sanatı (s. 106), İstanbul, Hil Yayın.

-Wintson, Brian (1987). Brunelleschi İçin Bir Ayna. Levend Kılıç içinde, Video Sanatı (s. 65-66), İstanbul, Hill 